\title{
Language Attitude of Indonesian Workers in Cruise Ship
} Holland America Line

\author{
Mega Williandani ${ }^{1}$, Rahayu Ningsih ${ }^{2}$, Mey Ramenawati Silalahi $^{3}$ \\ ${ }^{1,2,3}$ State University of Medan
}

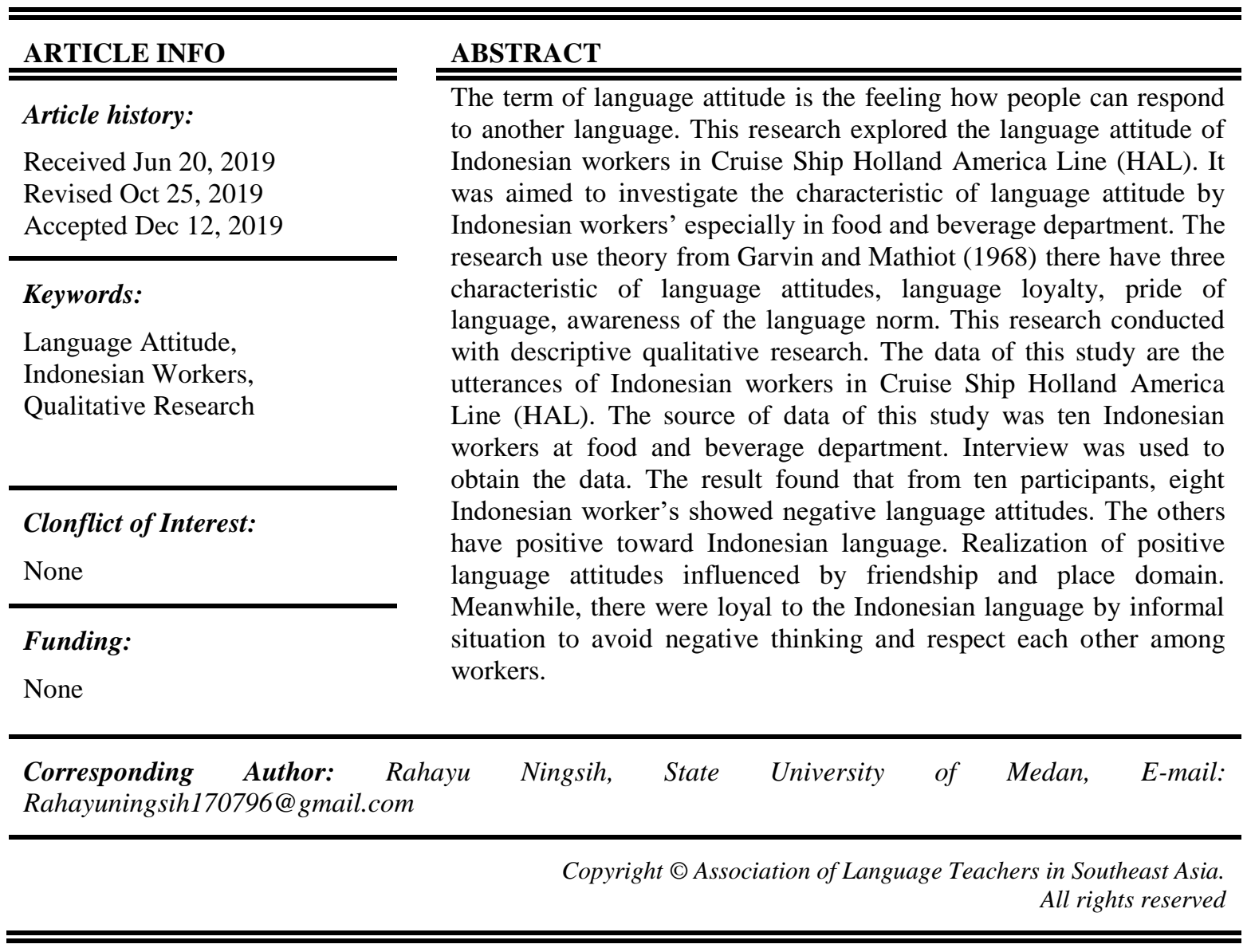

\section{Introduction}

Mancini (2011), states that the ship which conduct a trip in a high sea is called by cruise ship, with a lot of staff who's serving the passenger that want to be relax and enjoy their time without stressed from work or home. The biggest ship in the world can carry approximately 5400 passengers. According to Bow (2002), the fastest growing holiday in tourism sector is called the cruise industry. The most of the prominent cultural encounters on the ship is a food. Its importance to the cruise experience cannot be understated. Nearly a third of those responding to the Cruise Line Industry Association's poll, 'What I Like Best About Cruising', chose food as their favorite feature, the highest result reported in any category of the survey (Ross K. Dowling, 2006). Food and Beverage is one center of revenue in the cruise ship beside the rooms. So that's why the researcher interested to investigate the way of their communication between them and the guests in that ship. The cruise ship passenger is someone who has the high socioeconomic backgrounds (Mancini, 2011). They have different culture and characteristic especially in language used. The most common language that used on the cruise ship is English language. Most of the staff will be multi-lingual, as they come from around the world with the different accent languages spoken.

Based on researcher experience, Holland America Line (HAL) cruise ship have various ethnics of Indonesia such as: Balinese, Javanese, Bataknese, etc. It is interested to observation language used. The workers in this cruise ship has variation nationality too. Some of them come from Europe and Asia continent. Indonesia is 
one of them. Every ethnic has their original place and use their own native language. In this case, Indonesian workers tend to mixed Indonesian-English language for communicate.

This is the conversation of Indonesian worker's in cruise ship Holland America Line as the preliminary data.

Conversation I (the conversation occurred on $15^{\text {th }}$ October 2019)

AN : Sudah makan my men? (Have you eaten?)

HB : Yes, sudah. (Yes, already)

$\mathrm{AN}$ : Wak, kamu sudah nge punch in belom?

(Have you punch the attendance letter?)

HB : Belum ah. (Not yet)

AN : Tolong kamu punch kan lah sekalian. (Please help me to punch the attendance letter)

HB : Oke bro. (Alright)

Conversation II (the conversation occurred on $16^{\text {th }}$ October 2019)

HOD : Id kamu berapa? (Your ID number?)

AH : 174199.

HOD : Disini saya melihat performance kamu sudah oke, English sudah oke, functuality oke, guess satisfaction juga oke. (Here I see your performance is okay, English is okay, functuality is okay, guess satisfaction is also okay).

AH : Iya pak. (Yes, sir).

HOD : Apakah kamu setuju dengan penilaian ini? (Do you agree with this assessment?)

AH : Iya pak. Baik pak. (Yes sir. Okay sir).

HOD : apabila kamu setuju dengan penilaian ini silahkan tanda tangan disini ya. (if you agree with this assessment, please sign here).

AH : Baik pak. (okay sir).

HOD : Saran saya kepada kamu, kamu harus sering mengobrol kepada tamu agar tamu lebih mengenal kamu dan memberikan good komen pada akhir cruise. (My advice to you, you should often chat to guests so that guests know you better and give good comments at the end of the cruise).

AH : Baik pak terima kasih. (Okay sir, Thank you).

Conversation III (the conversation occurred on $17^{\text {th }}$ October 2019)

MOD : Mengapa tamu meja nomor 121 mengatakan bahwa kamu tidak menyediakan dietary food dengan baik?. Tamu tersebut marah dan keluar dari restoring dan mengadukannya kepada saya. (Why does the guest of table number 121 said that you don't provide diet food well? The guest was angry and came out of the restaurant and complained with me).

JJ : Sebenarnya pak, saya sudah menjelaskan kepada tamu tersebut tentang makanan yang dia minta, dan saya langsung menuju kitchen room dan meminta kepada koki tetapi makanan tersebut tidak tersedia. Seharusnya sebelum dinner, mereka menginfokan makanan yang tidak ada dan saya kembali ke restoran untuk memberitahu tamu tersebut. Dan mengajukan makanan lain sebagai pengganti tetapi tamu tersebut marah dan keluar restoran dan menyatakan kalau dia hilang selera makan. (Actually sir, I have explained to the guest about the food he asked for, and I went straight to the kitchen room and asked the chef but the food was not available. Before dinner, they had to inform them of food that didn't exist and I returned to the restaurant to notify the guest. And proposed another meal as a substitute but the guest was angry and left the restaurant and stated that he had lost his appetite).

MOD : Baiklah, saya akan membuat report tentang kejadian ini. (Okay, I will make a report about this incident).

The conversations above have been observed by the researcher through interview of the workers directly.

And it was really happened. Sometimes they tend to use Indonesian language or sometime mixed their language (Indonesian and English language). The first and second conversation, the language that they use in this conversation tended to be negative language attitude. The third conversation where the language tended to be positive language attitude. The researcher thinks that this phenomenon needs to investigate based on the theory of Garvin and Mathiot (1968).

Crystal (1997) said that, attitudes are how people feel about the language and is "a construct that elucidates linguistic behaviours or in particular" (Mamun et al., 2012). The attitudes can be positive or negative and both of them may influence people in learning second language. Some of them may feel happy to learn second language while others may not (Ellis, 1994). People's attitude toward language can be seen from how they think about language, how they use language, with whom they use, where and how often they use language. Language attitude studies will determine that people's attitude towards language might be positive or negative (Chalak \& Kassaian, 2010). Holmes (1992) states that the language in positive attitude might be 
can support in language maintenance where the minority language is highly valued, while language in negative attitude can accelerates the language shift, where an ethnic language is not highly valued.

Garvin and Mathiot (1968) said there have three characteristic of language attitude: (1) language loyalty means a society motivated of language speakers to maintain their language, and protect their language from other languages (2) language pride, means motivated the people to make their language as their identity and the unity of the society (3) awareness of the norms, is the biggest factor which contributes to the activity of using the language to motivates the people to use their language in carefully and politely (Masruddin,2014). The characteristic explained before, categorized as positive attitudes and vice versa.

Based on the phenomenon above, the investigation of the language attitude of Indonesian workers toward Indonesian language is important. They still loyal use Indonesian language's even though the rule is spoken English. The researcher thinks that there must be something that influences the attitude of Indonesian workers in Cruise Ship Holland America lines (HAL).

The previous research conducted by Leli Fitri Hasibuan (2018) and Deliana (2017), they have different result where the first research showed that they have positive attitude and the second research showed that they have negative attitude.

\section{Literature Review}

\subsection{Language Attitude}

Language attitude is the feeling that people have about their own language variety or the language variety of others. Language attitude is study how people react to language communications and how they evaluate the language based on language behaviour that they observed. Chalak and Kassaian (2010) stated language attitude that someone's towards a particular language might be either positive or negative. According to Garvin and Mathiot (1968:65), the characteristics of language attitude can be seen when someone is loyal to the language, s/he usually uses the language and maintains the language; when someone feels proud to the language, s/he is usually proud to use the language and makes the language as the symbols or as the identity, and when someone has awareness of language norm.

According to Fishman (1972), there are five domains of language use, namely family domain, friendship domain, religion domain, education domain, and employee domain. 1) Family domain means activity of speech community in family area. 2) Friendship domain means activity of speech community in colleagues. 3) Religion domain means activity of speech community in the same religion. 4) Education domain means activity of speech community around educated people. 5) Employee domain means activity of speech community on the working place.

\subsection{The Characteristic of Cruise Ship Workers}

Gibson (2008), however, found that some employees enjoyed the multicultural setting on board, and suggested it might provide a good example for land-based organization. Based on gender male is more dominant meanwhile female are focused in service position. It is supported by Nevins (2008), cruise liner had to work for 100 hours a week, with no days off and low payment rates.

The interviewees reported that the crew member of cruise ship have a length of contract and a little bit free time in their daily work on the board. Crewmembers sign 8-10 months contracts that the employer can terminate for any reason. These contracts are usually vague about specific work duties and stipulate 10-12 hours workdays, 7 days a week, without vacation or sick days. In the cruise ship, the staff doesn't have the privacy time because they should share their cabins, showers even the relaxation areas. According to Gibson (2008) said that, there are limited time to contact friends and family and this distance can impact on employee emotions.

According to Secvikova and Sehkaran (2011) found that working with people from different nationalities was a major difficulty for some employees. Every country has their own language. So, language is one of important to communicate each other. This differentiates made their mixed the languages.

\section{Method}

The method used was a qualitative research data in the form of utterances. According to Guba \& Wolf in Bogdan \& Biklen (1992:62) qualitative research is frequently called naturalistic because the researcher frequents places the event that she or he is interest in natural occurs. Qualitative research is divided into two studies: case study and multi-case study. This research applied descriptive qualitative research design. In this study, the researcher investigated the language attitude by Indonesian workers at the cruise ship Holland America Line (HAL). This data taken by interview 10 Indonesian worker's during their break time or vacation. The technic collection data was recorded from group of social media. The data obtained from this research were the analyzed based on theory Garvin and Mathiot (1968). The researcher tried to classify the 
language attitude used in that area based on the theory. The last, the researcher collected the data by underline's the text from their conversation to be analyze.

\section{Findings}

The findings of the study were formulated as following:

1. Types of language attitude of Indonesian workers at HAL were positive and negative language attitude. Eight (8) of Indonesian workers tended to be negative attitude at the same nationality. Furthermore, they also felt proud of the language and had awareness of the language norm by showing their consistency used their mother tongue or Indonesian language.

2. For the realization of positive language attitude of Indonesia workers at HAL (Holland America Line) cruise ship there were two domains found, namely: friendship, and place domain. Three friendship sub-domains in Indonesia workers. They are:(1) conversing with friends of the same nationality group, (2) conversing with friends who are not of the same nationality group, and (3) conversing with people of the same nationality group. There were five place domains identified. They are:(1) conversing inside the ship, (2) conversing outside the ship, (3) conversing from the guest house or repeated guest, (4) conversing by informal situation, and (5) conversing in formal situation.

3. For the reason of realization of language attitude of Indonesia workers at HAL (Holland America Line) cruise ship was found that there were two participants who were loyal to the language in the same nationality. It can be concluded that they thought of maintaining the language and valuing the language, they also felt comfort, respected by each other and avoid negative thinking between them by showing their identity.

After analyzing the data, there were some important points that have to be discussed in this study. The participants in this study that were Indonesian workers only had two domains of language use which were friendship domain, and place domain. The three domains were not realized in this study namely education domain, family domain and religion domain. It happened because based on the data observed, there were eight (8) Indonesian workers have negative attitude. Most of them, didn't care about their religion because that so many religions on there. They felt work individual and loneliness, they don't think about education because they just thought looking for the money and chase the time for take rest.

\section{Conclusion}

Based on the research findings that presented in the previous chapter, it can be concluded that Indonesian workers tended to negative language attitude rather than positive language attitude. The choice of language used in their work place is one of the factors that influenced them to be negative attitude towards Indonesian and English. The worker convenience in expressing their feelings, avoid misunderstanding and closer each other when used Indonesian language. Only two persons who loyal to Indonesia language because of their position and their partner in the same nationality. The other workers tended to be negative towards Indonesia and English language influenced into friendship and place domains. The selection words used influenced by the environment of the ship itself. Variation of language used in that ship especially Food and Beverage department are the dominant factor that Indonesian workers tended to be negative attitude.

\section{References}

Chalak, A.,\&Kassaian, Z. (2010). Motivations and Attitudes of Iranian Undergradute EFL Students towards Learning English. GEMA Online Journal of Language Studies.

Fishman, J.A. (1972). Language in Siciocultural Change. Standford: Standford University Press.

Fitri, D. (2018). "Language Attitude of Mandailingnese Teenagers in Desa Sidojadi Kecamatan Bukit Malintang Kabupaten Mandailing Natal”. Jurnal Linguistik Terapan Pascasarjana. ISSN 2407-7410, http://jurnal.unimed.ac.id/2017/index.php/JLTUnimed, 15 Februari 2018

Garvin, P.L \& Mathiot, M. (1968). The Urbanization of the Guarani Language: Problem in Language and Culture in Fishman, J.A. (Ed) Reading in Test Sociology of Language, Mounton:Paris-The Hague

Gardner, R, \& Lambert, W. (1972). Attitudes and Motivations in Second Language Learning. Rowley, Massachusetts: Newbury House.

Gibson, P. (2008). Cruising in the 21st century: Who works while others play? International Journal of Hospitality Management, 27(1), 42-52. http://dx.doi.org/10.1016/j.ijhm.2007.07.005

ITWF (International Transport Workers' Federation) (2005) 'What are Flags of Convenience?', www.itfglobal.org/flagsconvenience/sub-page.cfm

Likert, R. 1932. A Technique for the Measurement of Attitudes. Archives of Psychology 140: 1-55.

Larsen, S., Marnburg, E., \& Ogaard, T. (2012). Working onboard - Job perception, organizational commitment and job satisfaction in the cruise sector. Tourism Management, 33(3), 592-597. http://dx.doi. org/10.1016/j.tourman.2011.06.014 
Nevins, B. (2008). Cruise liners no luxury for crew as long hours, low wages prevail. http://articles.sunsentinel.com/1989-07-02/ news/8902180854_1_cruise-ships-carnival-cruise-lines-tropicanacruises

Ross K. Dowling. 'The Cruising Industry'. In Cruise Ship Tourism, edited by Ross K. Dowling (Cambridge, MA: CABI, 2006), 6.

Thamrin, T. 2018. "The language attitudes of Minangkabau people toward Minangkabau language and Indonesian Language". International Journal of Language Teaching and Education. Volume 02, No 2, ISSN Online: 2598-2303, https://doi.org/10.22437/ijolte.v2i2.506, 31 July 2018 